\title{
UMA ARMA PARA A GUERRA FRIA: KARL AUGUST WITTFOGEL E A CONSTRUÇÃO DO ORIENTE A PARTIR DE UMA LEITURA CONTROVERSA DO MARXISMO
}

Resumo Este artigo analisa a obra O Despotismo Oriental de Karl A. Wittfogel, geógrafo e participante da Escola de Frankfurt. A análise do livro, suas influências intelectuais e do seu contexto social de produção demonstra que Wittfogel se utiliza do legado marxista para construir um argumento teórico de que as sociedades asiáticas são em essência despóticas e que o comunismo seria uma evolução do despotismo face ao fenômeno industrial. Wittfogel tenta, portanto, instituir um marxismo anticomunista, defendendo o mundo ocidental no contexto da guerra fria.

Palavras-chave: Modo de produção asiático. K. A. Wittfogel. Despotismo Oriental. Anticomunismo. Teoria marxista.

\section{A WEAPON FOR THE COLD WAR: KARL AUGUST WITTFOGEL CONCEIVING THE EAST FROM A CONTROVERSIAL MARXIST INTERPRETATION}

Abstract: This article analyzes the work The Oriental Despotism of Karl A. Wittfogel, geographer and Frankfurt School member. The analysis of the book, its intellectual influences and its social context of production shows that Wittfogel uses the Marxist legacy to build a theoretical argument affirming Asiatic societies as essentially despotic. Communism is view as an evolution of despotism face industrial phenomenon. Wittfogel therefore tries to institute an anti-communist Marxism, defending the western world in the cold war context.

Keywords: Asiatic mode of production. K. A. Wittfogel. Oriental despotism. Anticommunism. Marxist theory.

\section{UN ARMA PARA LA GUERRA FRÍA: KARL AUGUST WITTFOGEL Y LA CONSTRUCCIÓN DEL ESTE A PARTIR DE UNA LECTURA CONTROVERSIAL DEL MARXISMO}

Resumen: Este artículo analiza el trabajo El despotismo oriental de Karl A. Wittfogel, geógrafo y participante de la Escuela de Frankfurt. El análisis del libro, sus influencias intelectuales y si su contexto social de producción demuestra que Wittfogel utiliza el legado marxista para construir un argumento teórico indica las sociedades asiáticas como esencialmente despóticas. El comunismo sería una evolución de estas sociedades ante la industrialización. Wittfogel tiene la intención de instituir un marxismo anticomunista, posicionándose como un defensor del mundo occidental en el contexto de la guerra fría.

Palabras clave: Modo de producción asiático. K.A. Wittfogel. Despotismo oriental. Anticomunismo. Teoría marxista.

\footnotetext{
${ }^{1}$ Universidade Federal do Rio Grande do Sul, Departamento de Geografia, Porto Alegre, Brasil, brenoviotto@hotmail.com, https://orcid.org/0000-0003-3204-8992
} 


\section{Introdução}

O Despotismo Oriental de Karl August Wittfogel é uma obra polêmica que dividiu opiniões. O livro analisa as sociedades orientais e condena o socialismo real, mobilizando para isso obras marxianas e marxistas. Antigo participante do Comintern, o Despotismo mostra a nova face de Wittfogel, anticomunista que havia denunciado colegas nas comissões macarthistas.

O processo de publicação da obra foi controverso, seja nos Estados Unidos, seja no exterior. O livro foi avaliado pela Editora Universitária de Oxford e foi recusado, pois o avaliador destacou que seu viés anticomunista se articula com dificuldade ao argumento teórico do texto, paralelamente, alguns editores aceitaram publicar a obra, caso fossem suprimidas as partes finais sobre Marx, Lenin, Stálin e Mao (Linton, 2011, p. 80-82).

Segundo Perry (1987, p. 78), de uma forma geral, o livro é historicamente mal embasado, sofre de um brutal etnocentrismo e subestima o papel da propriedade privada em sociedades como China e Índia. Entretanto, o Despotismo é uma obra de fôlego e reflete a grande erudição acumulada por seu autor. Ela sintetiza a aplicação das posições políticas de Wittfogel para compreender o oriente e, nesse sentido, cabe destacar que existe, como pano de fundo, uma preocupação geopolítica, pois o autor equivale as sociedades soviética e chinesa, tendo como objetivo prever politicamente seu comportamento (Linton, 2011, p. 73-74). O comunismo seria a face moderna da restauração de um poder oriental despótico e no afã de compreender a lógica dessas sociedades, Wittfogel acredita ser possível prever seu comportamento por meio do delineamento de aspectos econômicos, sociais e históricos. Evidentemente, a imbricação da lógica social soviética e chinesa sacrificou a objetividade de sua análise, pois a China e Rússia possuem formações históricas distintas. Paralelamente, é notória a retórica de sua obra, que carrega uma mentalidade maniqueísta, coerente com o macarthismo e com a Guerra Fria (Linton, 2011, p. 74 e 86).

A publicação do livro de Wittfogel, em 1957, após a revolução chinesa surge em um momento fundamental da Guerra Fria, justamente quando a luta no terceiro mundo se intensifica através dos chamados conflitos indiretos. Mesmo com a trégua na Guerra da Coreia o perigo vermelho ainda rondava o mundo.

Em 1956, um ano antes da publicação de O Despotismo, Wittfogel participa de uma coletânea de textos que conta com a contribuição do geógrafo $C$. O. Sauer e 
de antropólogos culturais. No texto intitulado "The Hydraulic Civilizations", Wittfogel adianta ideias de $O$ Despotismo e assume um tom claramente anticomunista. Esse artigo é uma síntese de suas hipóteses, a saber: (1) a irrigação agrícola é responsável pela revolução urbana na Antiguidade; (2) ela também cria condições para uma difusão ou expansão territorial das sociedades hidráulicas, para além das áreas áridas e semiáridas; (3) o modo de produção asiático com suas implicações econômicas, políticas e sociais foi difundido na Rússia a partir da invasão mongol, povo este que incorpora tal organização após ter conquistado os chineses; (4) o modo de produção asiático representa a perpetuação constante de uma mesma ordem tecnológica e política; (5) o comunismo é uma resposta das sociedades orientais à industrialização e à modernização. Wittfogel (1956, p. 162) destaca ainda a expansão do colonialismo comunista e usa a dicotomia que põe, de um lado, a sociedade comunista totalitária e, de outro, a democrática ocidental.

Em contrapartida, existe um revés que recai sobre a obra, pois, em 1956, é publicado o relatório secreto de Krushchov. Concomitantemente, temos uma fase em que as tensões entre URSS e EUA diminuem em função dos eventos na Hungria e devido à política da convivência pacífica. Enquanto isso, a China de Mao acusa a URSS de revisionismo e não confere importância às denúncias de Krushchov contra Stálin. Para os chineses, os EUA continuam sendo inimigos ativos devido à proteção concedida à Taiwan e à ocupação militar maciça no Extremo Oriente. Enquanto a URSS tinha a convicção de que o capitalismo entraria em crise profunda, a China, sob o governo de Mao, almejava se tornar uma grande potência mundial e deter a tecnologia da bomba nuclear. Certamente, tal fato, apenas um ano antes da publicação do livro, colocou na berlinda a teoria de Wittfogel.

Assim, o isolamento intelectual de Wittfogel se agrava quando, na década de 1960, ocorre a cisão sino soviética, ou seja, este novo acontecimento contradiz sua tese. Nesse sentido, a eclosão da guerra do Vietnã, diferentemente do caso coreano, provoca um aprofundamento do distanciamento entre soviéticos e chineses, sendo os vietnamitas apoiados apenas pela URSS. Outro elemento que contribui para o ostracismo após a publicação é o fato de Herbert Norman ter se suicidado, em 1957, sob circunstâncias misteriosas. Herman era diplomata canadense, estava no Egito e foi implicado por Wittfogel em seu depoimento para uma comissão macarthista de caça aos comunistas. Apesar disso, o livro de Wittfogel teve impacto e uma relativa aceitação, pois foi lido por vários especialistas, sendo criticado por motivos diversos (Linton, 2011, p. 85). 
Witffogel, de uma forma geral, no momento da publicação de O Despotismo, deixou seus críticos sem resposta. Adorno e seus antigos colegas da escola de Frankfurt receberam a obra com apatia, no entanto, apesar de controversa, a publicação restaura sua reputação de pesquisador após a colaboração com os macarthistas (Linton, 2011, p. 76-87).

Nos valendo da abordagem contextualista (Berdoulay, 2003), propomos neste artigo a recuperação da principal obra de Wittfogel para compreender como foi construído o seu marxismo anticomunista, que interpretou a obra de Marx e Engels seletivamente, recuperou o argumento de Bakunin contra o Estado para criticar a URSS e, sobretudo, evocou sobre o oriente um essencialismo recorrente dentre vários iluministas europeus do século XVIII, a saber, o de que à leste se encontram sociedades despóticas e imutáveis em termos políticos e culturais. São povos sem história, condenados apenas a uma transição de poder, em que não existe luta de classes, uma visão que carece de comprovação empírica e que, ao fim e ao cabo, reafirma a cultura ocidental como a única capaz de libertá-los.

Outrossim, com base em Bourdieu (2001 e 2003), tentamos investigar quais são as mudanças de posição de Wittfogel nos campos político e científico. Prestigiado dramaturgo, sinólogo, geógrafo e militante comunista em seu país natal, Wittfogel chega aos EUA e permanece por um breve período apático e distante da vida política. Logo após, ele se engaja na antropologia cultural estadunidense, trabalhando no grupo de Franz Boas e se casando com uma de suas alunas. Sua prestigiosa posição no campo científico da antropologia é posta em risco a partir de sua participação em inquéritos macarthistas que investigavam intelectuais comunistas. Após essa caça às bruxas, Wittfogel publica o Despotismo aspirando não apenas o prestígio acadêmico, mas que suas ideias tivessem influência sobre políticos e diplomatas estadunidenses. Ele aspirava ganhar capital cultural e ao mesmo tempo ampliar seu capital social dentre a alta política dos EUA. A repercussão de tal virada é sentida também no campo do marxismo, uma vez que vários autores, como veremos, acabam por descartar o debate teórico sobre o modo de produção asiático.

Na parte final do texto, a comparação com H. Arendt não é fortuita, pois ela e Wittfogel são intelectuais de esquerda que fugidos da Alemanha nazista se aculturam no ambiente intelectual estadunidense e ambos acabam integrando a esquerda anticomunista, que ataca frontalmente o socialismo real, possivelmente com apoio institucional dos EUA. Assim, acreditamos que a combinação da análise 
epistemológica, do contexto histórico e da trajetória intelectual nos permite delinear uma nova leitura de Wittfogel em que sua produção teórica é lida como consequência de suas opções políticas e de suas aspirações no campo científico e político.

\section{Desenvolvimento - Análise de O Despotismo}

Vamos agora analisar a magnum opus de Wittfogel de forma mais linear. Logo no início se nota que o autor delimita o objeto do estudo na compreensão da peculiaridade da sociedade "semigerencial oriental de poder despótico" e na sua fase subsequente, ou seja, a ascensão do totalitarismo comunista como uma manifestação mais intensa e moderna de autoritarismo. Então teríamos, de um lado, as sociedades multicentradas que resultariam na democracia (Ocidente e Japão) e, de outro, as sociedades totalitárias correspondentes ao comunismo e ao fascismo. Wittfogel (1966, p. 15), nesse contexto, defende claramente a necessidade de grandes teorias explicativas, ou ainda, uma "revolução macroanalítica nas ciências sociais".

Palerm (1978, p, 23) resume as características do modo de produção asiático segundo a interpretação de Wittfogel pelos seguintes aspectos: (1) ausência da propriedade privada, (2) aldeias isoladas e autossuficientes, (3) ligação entre agricultura e artesanato, (4) grandes obras realizadas pelo Estado, (5) a burocracia do Estado como força política, (6) a presença do déspota e (7) a existência de estagnação e a impossibilidade de se gerar formas socioeconômicas avançadas. Palerm (1978, p. 59) demonstra como no seu raciocínio, frequentemente, o Estado se mostra como mais forte que a própria sociedade, por isso a estagnação, ou seja, afora a própria burocracia, nenhuma classe social é capaz de mudar o modo de produção asiático. Deriva-se, então, a concepção de que em tais sociedades não existe luta de classes.

$\mathrm{Na}$ introdução d'O Despotismo, Wittfogel faz um balanço de sua trajetória sem enfatizar seu engajamento político no marxismo ortodoxo, além de caracterizar o despotismo a partir de um "nexo geoinstitucional", postura que deixa transparecer seu determinismo geográfico, ou seja, o meio geográfico determina a arquitetura institucional da sociedade. De acordo com esse nexo, surgem as sociedades hidráulicas que necessitam de água para sustentar a produção agrícola, 
organizando-se em ambientes semiáridos para se expandirem rumo aos meios áridos e úmidos (Wittfogel, 1966, p. 21).

Wittfogel insere na sua análise a apreciação das condições culturais e institucionais na dinâmica das sociedades orientais, influência clara da antropologia cultural estadunidense, que ele se dedicou ao chegar da Alemanha. Assim, o quadro natural persiste como fator determinante, mesmo que ele admita que a natureza se transforme diante do progresso técnico. Segundo suas palavras:

Primeiro, a ordem institucional, a sociedade hidráulica, não pode se explicar apenas por referência aos fatores geográficos, tecnológicos e econômicos. Mesmo que a resposta ao ambiente seja um eixo chave, só desempenha um papel formativo sob condições culturais específicas (Wittfogel, 1966, p. 191) ${ }^{2}$.

Mesmo que o autor tente relativizar, em última instância, persiste 0 determinismo ambiental, uma vez que a cultura do despotismo está ligada ao quadro institucional gerado como resposta ao meio. Todas as sociedades orientais apresentam características com um viés organizativo e militarizado, ânsia por expansão territorial e por conquistar outros povos. Assim, para nosso autor, a cultura e a ordem institucional têm mais peso nas mudanças da organização social do que as inovações tecnológicas, incapazes de alterar estruturalmente o despotismo.

Declaradamente, Wittfogel (1966, p. 458) adere à crítica ao marxismo, acusando-o de não considerar os aspectos culturais, sendo o modo de produção asiático visto como um modelo civilizacional em que "[...] as culturas podem compartilhar muitos traços tecnológicos, artísticos, literários e religiosos, sendo, entretanto, mundos a parte do ponto de vista da estrutura social" (Wittfogel, 1966, p. 465). Contudo, na prática, sua análise revela um esquema homogeneizado em que o mundo oriental tem características básicas bem definidas e estáticas. É como se os valores culturais e estéticos não pudessem estar dissociados da racionalidade política de centralização do poder, fato este gerado pela necessidade de irrigação para a promoção da agricultura.

Assim, os avanços e trocas culturais são interpretados comumente como processos de "orientalização" e, em oposição ao oriente, está a sociedade europeia multicentrada e fundamentada na propriedade privada. Contraditoriamente, ao comparar Ásia e Europa, o autor pondera que "se são iguais as condições históricas, uma diferença natural maior é causa possível das diferenças institucionais decisivas" (Wittfogel, 1966, p. 31). Afirma-se então que a agricultura de chuvas estaria na raiz

${ }^{2}$ Tradução nossa, assim como as demais em língua estrangeira no decorrer do texto. 
das instituições europeias delineando sua história, enquanto a agricultura irrigada daria origem aos "métodos hidráulicos de controle social" (Wittfogel, 1966, p. 31). Cremos que essa categorização simplifica os processos de desenvolvimento histórico e a dinâmica geográfica das várias civilizações.

Desse raciocínio, Wittfogel deriva uma teoria, de cunho antropológico, em que dentre os homens primitivos encontraríamos dois grandes modos de vida que se opõe. De um lado temos os povos nômades, seminômades e sedentários ligados à agricultura pluvial, uma modalidade agrícola de risco, que exigiria mais trabalho. Do outro lado, encontramos os povos de agricultura hidráulica, que por terem trabalhos coordenados conseguiam constituir uma burocracia organizada e opressora (Wittfogel, 1966). Assim, a oposição desses dois modos de vida favoreceria a expansão dos povos hidráulicos que conquistam e exploram as comunidades baseadas na agricultura pluvial, no pastoreio ou na caça. Em tal quadro, as sociedades hidráulicas teriam a capacidade de, facilmente, dominar os povos de agricultura pluvial ou os nômades, com menor força bélica e organização administrativa. Uma vez que existe o domínio de técnicas básicas de controle, a agricultura irrigada partiria de áreas semiáridas para a conquista de meios áridos e úmidos, subjugando nesse processo os povos com outros modos de vida. No entanto, ele não explica como os mongóis, essencialmente pautados em um nomadismo tribal federalista, conquistaram os chineses "hidráulicos".

O modelo interpretativo exposto admite ainda que nas sociedades pluviais, por não existir um controle rígido do Estado ou de uma casta, ocorre a geração espontânea da ideia de propriedade privada, enquanto na sociedade de agricultura irrigada tal ideia seria inibida pelo déspota e sua burocracia. A propriedade somente existiria na medida em que fosse lucrativa para o déspota (Wittfogel, 1964, p. 23-26).

Para Wittfogel, a China constitui um grande espaço de referência para compreensão das sociedades orientais, pois encontramos ali o estereótipo perfeito do modo de produção asiático que, através da força militar mongol, teria se expandido para a Rússia - para Marx, a sociedade indiana, mais do que a chinesa, seria a referência para compreensão do Oriente. Como as sociedades nômades teriam baixo nível de racionalidade hidráulica, o papel dos mongóis é de mero transmissor do sistema incorporado na China. Wittfogel, entretanto, explora pouco as relações entre a sociedade indiana e a chinesa, ou ainda, entre o mundo árabe e as demais sociedades asiáticas. Seu método compara as sociedades orientais de 
maneira estática, a partir de recortes temporais feitos sem justificativa, com ênfase seletiva no tocante às relações entre as civilizações hidráulicas.

As sociedades hidráulicas conseguem desenvolver uma divisão do trabalho complexa, com um exército profissional, renda de corveia e se estabelece uma equivalência entre a liderança política e a "hidráulica", segundo Wittfogel (1966, p. 41-49), aspectos que surgem precocemente. O imperativo hidráulico fomenta a astronomia, a matemática, a escrita e os transportes sejam fluviais, seja o estabelecimento de uma rede de estradas. A construção de tumbas e edificações monumentais são, para nosso autor, outros traços da sociedade oriental (Wittfogel, 1966, p. 41-53).

A cidade asiática surge como um acampamento principesco ou burocrático e, descartando a hipótese da pequena propriedade mercantil, para Wittfogel a indústria e a manufatura no oriente nascem em grande escala controladas pelo Estado. Nesse sentido, a corveia asiática, diferente da feudal, recai sobre todo o povo, ideia semelhante ao que Marx caracterizava como "escravidão generalizada". O Estado, além de gerenciar o trabalho coletivo, destrói toda cristalização de corpos políticos independentes, sob o risco de ameaçar sua hegemonia. Além disso, a força estatal desemboca em um controle não apenas dos indivíduos, mas também da informação gerada sobre a população, uma vez que no oriente encontramos precocemente censos, anais, dados, etc. (Wittfogel, 1966, p. 68-71). Concursos públicos, controle fiscal ou mesmo os censos são apresentados como elementos de controle social e tolhimento de liberdades.

Também seriam traços orientais a presença dos serviços secretos - a Índia, por exemplo, teria estabelecido um na época Gupta (320-550) -, o monopólio do correio e da distribuição da informação - como entre os incas ou chineses -, a presença do confisco administrativo e político, inclusive de heranças, além de uma força militar regular, profissional e constante (Wittfogel, 1966, p. 78-97). Tais traços são apresentados de maneira fragmentária e descontextualizada, sendo que sua conclusão é de que o Estado ocidental protege os capitalistas nascentes, enquanto o modo de produção asiático protege a economia estatal de base agrícola. Pode-se derivar uma teoria explicativa dos países subdesenvolvidos e de seu atraso econômico, supostamente relacionado à interferência do Estado na economia, ou ainda, da falta de uma base institucional para o desenvolvimento pleno do capitalismo. Isso porque seu modo de produção asiático é extremamente flexível, 
abrangendo extensas áreas geográficas, sendo possível ainda identificar "traços" orientais.

Quanto ao movimento de colonização europeu na Ásia, Wittfogel reconhece que foi criada uma mistura de instituições administrativas que, em parte, reproduziam traços orientais e, em parte, possibilitaram "a exportação econômica" de algumas instituições ocidentais (Wittfogel, 1966, p. 482). Pouco é dito sobre as relações de exploração ou sobre os enlaces entre metrópole e colônia.

Outra caraterística importante é a reafirmação de Wittfogel das sociedades orientais teocráticas, certamente, uma concepção que pode ser problematizada, por exemplo, ao se vislumbrar a história da China. Cheng e Fu (1995, p. 25) destacam o fato de Wittfogel ver o despotismo oriental como uma grande entidade homogênea, tanto no tocante aos aspectos geográficos, quanto aos históricos. Nesse sentido, sua teoria geral é simplista ao explicar a longa e conturbada história chinesa e isso fica evidente quanto nos deparamos com o papel da teocracia na China.

É interessante notar que na mitologia chinesa existe uma associação simbólica clara entre a água, o rio amarelo, a figura do déspota e a imagem do dragão que é constituída a partir da dinastia Xia ou Hsia, uma das primeiras a se consolidar no século XXI a.C. O primeiro imperador $\mathrm{Yu}$, o grande construtor, é tratado sob status de Deus que tem o poder de controlar as águas conduzindo a sociedade e manifestando seu descontentamento através das cheias e situações extremas ligadas à dinâmica fluvial. Claramente, existe uma associação entre o primeiro imperador e a figura de um tirano que usa medidas fortes para governar (Zhao, 1989, p. 233-235). Vale lembrar que nesse período, a dinastia exercia seu poder basicamente nas intermediações do rio Amarelo, ou seja, em um território menor do que a China atual.

Wittfogel, no entanto, admite a possibilidade de que, na China antiga, encontraríamos uma sociedade organizada de acordo com um feudalismo asiático, ou ainda, uma estrutura em que o modo de produção asiático não teria se consolidado, contudo, possuiria traços orientais. Essa permeabilidade dos aspectos culturais permite reafirmar que Alexandre, o grande, teria incorporado traços asiáticos, assim como o Império Romano. Perceberemos que Wittfogel (1966, p. 5967) defende que parte do mundo antigo europeu estaria sob a égide do modo de produção asiático, sem, em nenhum momento, problematizar a questão do modo de produção escravista posta por Marx e Engels. 
Mesmo que na época do Império Romano encontremos uma unidade política importante, com traços orientais, após a destruição de sua parte ocidental, a Europa estaria livre do cesaropapismo, ou seja, a partir das invasões bárbaras se criaria uma relativa independência entre igreja e corpo estatal, quadro que se reafirma após o surgimento do protestantismo. O restante da Europa estaria exposto às tendências orientais vindas do Império Bizantino, da Turquia, dos árabes e das invasões dos povos do oriente, de modo que Wittfogel (1966, p. 246) afirma que o costume estabelecido, logo após a queda de Roma, de beijar os pés do soberano seria um traço oriental, além de classificar a Espanha islâmica como uma sociedade hidráulica. Em paralelo, o feudalismo é responsável pelo esmaecimento da teocracia, uma vez que encontramos na Europa uma fragmentação política e religiosa. Exatamente como Montesquieu em O Espírito das Leis, Wittfogel (1966, p. 133) caracteriza a aristocracia como uma barreira ao poder do monarca e defende a tendência de que, no despotismo, a busca pelo poder se torna ilimitada.

O autor não diz, absolutamente nada, sobre Luís XIV e sua concentração de poder, o que demonstra como seu pensamento é pouco dialético, pois ele se esquiva de analisar as tendências à diluição do poder no oriente, da mesma forma que ignora a centralização do poder no ocidente.

\section{Classificação do sistema hidráulico}

Wittfogel define um sistema de classificação das sociedades orientais, definindo-as como agrogerenciais e agroburocráticas. As agrogerenciais se desdobram em três tipos: (1) as sociedades hidráulicas simples (Havaí, Peru incaico, Suméria, Egito faraônico) em que existe propriedade privada, mas ela é facilmente desapropriada, pois é concedida pelo Estado. (2) Sociedades hidráulicas semicomplexas (Índia, Mesopotâmia, Pérsia, Monarquias helenísticas do Oriente Próximo, interlúdios no Império Romano, Oriente Próximo islâmico, Sociedade Mameluca, Turquia otomana, sociedade Maia e México pré-colombiano) em que parte dos artesãos possuem propriedade privada e desenvolvem suas atividades de maneira autônoma. Nessas sociedades, a propriedade privada é rústica, ou seja, sua valorização depende da burocracia, além da existência de terras privadas e a formação de um mercado paralelo ao do Estado. (3) Por fim, temos a sociedade hidráulica complexa em que existe a propriedade privada, porém mais da metade 
das terras cultivadas está nas mãos da burocracia a serviço do Estado (Rússia em 1762 e a China) (Wittfogel, 1966, p. 297-319).

Wittfogel designa ainda as chamadas sociedades hidráulicas marginais, ou seja, lugares onde a irrigação não teve um papel preponderante como na Rússia ou no Império Bizantino. A Rússia, por exemplo, seria "zona hidráulica marginal”, o que denota a importância do quadro natural e demonstra igualmente como o despotismo pode transbordar sua delimitação geográfica incorporando novos territórios. Inclusive, as capitais das sociedades orientais são postas estrategicamente em áreas limítrofes entre territórios hidráulicos (semiárido) e não-hidráulicos (Wittfogel, 1966, p. 214-224). Além das zonas marginais, encontraríamos as zonas submarginais onde estão os regimes que sofreram contato com algumas das características orientais isoladamente.

Deriva daí, também, o conceito de densidade hidráulica que descreve a coesão territorial e controle social do Estado, ou seja, o núcleo hidráulico possuiu o ápice do poder e sua eficiência, enquanto na periferia sua fronteira é permeável e frágil (Wittfogel, 1966, p. 227). Essa ideia se assemelha bastante a de área cultural dos antropólogos culturais estadunidenses.

Assim como assinalou Sofri (1977, p. 111), Wittfogel admite a taxa de corveia nas sociedades asiáticas como uma forma de garantir a durabilidade e a estabilidade da economia, que a seu ver é essencialmente agrícola. Contudo, a divisão de classes se dá entre a burocracia estatal e o restante da sociedade, o que permite identificar três extratos básicos: o soberano, a burocracia e os governados.

Em O Despotismo, contradizendo seu estudo sobre a dinastia Liao, Wittfogel (1966, p. 227) admite que, na China, os invasores estrangeiros num primeiro momento fragmentam o território para logo após, se converterem ao agrodespotismo. Mesmo assim, nosso autor continua sustentando a não absorção demográfica, ou seja, existe o convívio comum sem uma miscigenação profunda entre invasores e conquistados, pois mesmo que ocorra a inserção de uma nobreza exógena - ligada, por exemplo, às tribos Liao, povo originário da Manchúria - a união completa só é possível com o fim das divisões sociais e culturais (Wittfogel, 1966, p. 370).

Wittfogel se interessou principalmente pelas dinastias ligadas aos povos nômades da Ásia central. Como pontua Gelber (2012, p. 130-131), durante a dinastia Yuan (1271-1368), de origem mongol, existiu o incentivo à perpetuação do sistema de aldeias de agricultura irrigada, mas Wittfogel pouco fala que a dinastia 
Ming (1368-1644) foi uma era de estímulos para o estabelecimento de contratos agrícolas e arrendamento de terras. Ainda durante o governo Ming, contemporâneo às grandes navegações, o governo imperial diminuiu as restrições ao comércio, resultando no florescimento de uma plêiade de pequenos negócios ligados ao artesanato, existindo paralelamente à exportação de especiarias.

O Japão é classificado como uma sociedade feudal, pois lá não existe o desenvolvimento de uma burocracia densa, apesar de termos um sistema de irrigação significativo. A propriedade privada tem importância e o poder político esteve fragmentado, pois diferentemente da China confucionista, o Samurai como burocrata ilustrado desenvolve uma consciência individual (Wittfogel, 1966, p. 233). Mesmo que Wittfogel admita as relações profundas entre China e Japão, tal elucubração nos parece problemática, porque mesmo que concordemos com o fato da sociedade japonesa ser feudal, não é possível negar que existiram centralizações políticas como ascensão do xogunato Tokugawa. Não se fala de traços asiáticos para o Japão, o que o ilustra bem o pontilhismo do método wittfogeliano, ou seja, sua capacidade de comparar os recortes espaço-temporais isolados que convêm para sua hipótese.

O mesmo se aplica, por exemplo, para sua recuperação histórica da sociedade russa, povo que seria feudal até antes das invasões mongólicas, possuindo uma milícia livre (Druzhina), conselhos populares e um senado aristocrata. As influências bizantina e mongol introduzem a burocracia, a teocracia e as leis hidráulicas (Wittfogel, 1966, p. 234-236). Para o autor:

A influência de Bizâncio sobre a Rússia kieviana foi grande,
porém foi principalmente cultural. Como a influência da China
sobre o Japão não alterou seriamente as condições do poder,
classes e propriedade. A influência da Turquia otomana sobre a
Rússia do século XVI estimulou um regime que já era
orientalmente despótico, mas não o criou. O governo tártaro foi o
único entre as três grandes influências orientais que afetaram a
Rússia, e foi decisiva tanto na destruição da sociedade kieviana
não oriental quanto na fundamentação do estado despótico da
Rússia moscovita e pós-moscovita (Wittfogel, 1966, p. 259).

Anteriormente, o nosso autor defendia a revolução de 1917, agora a sua leitura admite que tal evento destruiu a possibilidade de constituição da democracia na Rússia (Wittfogel, 1966, p. 27). O comunismo inaugura as sociedades agroburocráticas, uma resposta do despotismo oriental ao processo de modernização e industrialização. Em tal regime, todas as "relações sociais não 
governamentais" seriam destruídas, conformando um despotismo pior do que nas sociedades hidráulicas clássicas (Wittfogel, 1966, p. 138-140).

\section{Despotismo, ideologia e estagnação histórica}

Os regimes despóticos agrícolas exercem o controle em aldeias isoladas mantendo seu atraso tecnológico, contraditoriamente, sendo este um elemento gerador de lucro e controle social. A figura da comuna rural ou aldeia autossuficiente e com baixa divisão do trabalho foi uma instituição discutida por Marx e que caracteriza a formação social asiática. A indústria, por sua vez, não é controlada firmemente, porque ela não é tão lucrativa como a agricultura, aliás, Wittfogel (1966, p. 262) diz que nenhuma sociedade oriental tradicional conseguiu se industrializar, ignorando completamente o papel das manufaturas na China e na Índia.

O Estado oriental, nesse sentido, mobiliza elementos superestruturais para salvaguardar o controle social. A educação despótica é vista como uma forma de controle do pensamento ou uma mobilização institucional para formar as elites dóceis. Wittfogel descarta a possibilidade da democracia nas aldeias e expõe que a questão ideológica é um tema de preocupação permanente para a burocracia. Nesse sentido, o chefe da aldeia tem uma ligação tênue com a burocracia estatal (Wittfogel, 1966, p. 143-146).

O policiamento na sociedade oriental é também um elemento constante, pois tanto na manufatura, quanto na agricultura, existem os agentes punitivos, os coletores de impostos e pouca importância é dada à magistratura das aldeias. Diante disso, a aldeia tem uma autonomia parcial, pois está submissa ao poder central. Assim, o sistema hidráulico admite apenas as liberdades politicamente irrelevantes, como a das corporações de artesãos, das religiões secundárias ou das próprias aldeias (Wittfogel, 1966, p. 150-152).

A lógica administrativa da sociedade asiática se resume a: (1) manter a agricultura em funcionamento, (2) assegurar a ordem, (3) garantir as pressões sobre o trabalho e os impostos de maneira aceitável e (4) impedir que conflitos internos e externos que destruam a coesão social (Wittfogel, 1966, p. 154).

A estratégia política do despotismo é fragmentar todos os grupos que não pertencem à burocracia como, por exemplo, os comerciantes ou camponeses, algo que não teria ocorrido na Europa. Nesse sentido, Wittfogel (1966, p. 155) determina uma racionalidade ideal para o estado despótico que é essencialmente política e não 
econômica. Tal postura contrasta com sua crítica aos geopolíticos, feita na juventude, que colocava a economia e a natureza como as principais forças motrizes do desenvolvimento social.

Ao assumir a hipótese weberiana de racionalidade econômica distinta no oriente, ele delineia uma lógica de autoperpetuação da burocracia que se consolida para e pelo poder. Para essa argumentação, Wittfogel despreza o humanismo chinês e demonstra como a burocracia monopoliza a justiça oficial, os artigos de luxo e a ostentação, bem como os meios de punição e policiamento que recaem sobre todos os cidadãos. Daí a associação entre a burocracia e o hedonismo, tema tradicional do orientalismo europeu do século XIX.

Evocando o pensamento de John Locke, o autor demonstra como o poder corrompe o Estado, o fazendo de maneira completa nas sociedades asiáticas. A benevolência do líder e da burocracia só pode ser caracterizada como fábula e a revolução no oriente só muda os agentes dominantes, sem alterar a estrutura de funcionamento social (Wittfogel, 1966, p. 163).

A incorporação de conceitos da antropologia cultural faz com que Wittfogel absorva uma dimensão psicológica da análise do modo de produção asiático. Ou seja, a superestrutura dessas sociedades é moldada para que exista uma aceitação do despotismo, da tirania e do totalitarismo, através de rituais, de controle sobre as comunas e de outros mecanismos de coerção individual (McFarlane et al., 2005, p. 286). Assim, o terror entra em cena como um elemento que confere coesão. A violência, a tortura, o poder judicial, a crueldade, a afirmação do poder por atos públicos, a intimidação e a exigência da violência constituem fatores que compõem a superestrutura. A prosternação, comum da reza à deferência às autoridades, é o gesto que simboliza a dominação engendrada pelo despotismo agrário. A própria burocracia não estaria completamente livre desse sistema, uma vez que, o alto comando estatal está sujeito à eterna suspeita (Wittfogel, 1966, p. 181-191). Tais elementos se intensificam ou são restaurados pelos novos regimes comunistas, pois a doutrina ideológica substitui a igreja dando coesão à sua superestrutura (Wittfogel, 1966, p. 362).

Frente a essa dinâmica social, os camponeses trabalham 0 mais vagarosamente possível, o povo em geral é pouco industrioso, pois tem consciência que o Estado sufoca o sucesso individual, confisca a prosperidade alheia ou os rendimentos excessivos. A luta de classes no modo de produção asiático permanece paralisada, uma vez que o povo em geral, fragmentado, busca apenas pequenas 
vantagens pessoais. Paralelamente, a burocracia se envolve em lutas internas por vantagens, o que produz uma estrutura hierárquica rígida e estacionária.

As desapropriações materiais implicam na perda da honra e da vida, existindo em alguns casos a polarização entre a burocracia civil e a militar (Wittfogel, 1966, p. 382-383). Une-se a esse quadro pessimista a concepção que os concursos públicos na China são uma mera ilusão de ascensão social, uma vez que apenas as famílias enriquecidas e/ou os descendentes de funcionários públicos são capazes de lograr o sucesso. Na dinastia Yuan, por exemplo, 74\% dos aprovados seriam descendentes de funcionários, $11 \%$ membros da casa reinante e 15\% seriam plebeus. Assim, para o autor, os concursos não atingiram seu objetivo, no entanto, ele próprio admite que o tema deve ser analisado com mais profundidade (Wittfogel, 1966, p. 396-399). Entretanto, Chang (2003, p.138-39), por exemplo, demonstra como, no ocidente, o nepotismo e a indicação política foram componentes banais do corpo burocrático até pelo menos fins do século XIX.

Tal prospecto autoriza Wittfogel a associar a falta de mobilidade social oriental à ossificação social da URSS. Bem ou mal, a fase inicial da revolução reconfigurou profundamente a estrutura social russa, seja em função da guerra civil, seja devido à perpetuação de uma ideologia igualitarista. A consolidação de uma burocracia partidária e estatal induziu a uma reprodução social, contudo, isso não nos parece especificidade de nenhum sistema social.

Como no oriente a burocracia comunista exerce o poder total, Wittfogel (1966, p. 414-415) acredita que no capitalismo existam forças sociais múltiplas que tendem ao monopólio, mas "se equilibram entre si para impedir a hegemonia exclusiva de uma delas", um aporte explicitamente liberal e otimista quanto ao prognóstico de Lênin a respeito da formação de monopólios.

A partir dessa interpretação, a coletivização stalinista representa a destruição da pequena propriedade camponesa e o fortalecimento do Estado, pois no modo de produção asiático a terra é propriedade produtiva do Estado (Wittfogel, 1966, p. 340).

\section{A condenação do comunismo}

A última parte do Despotismo pretende fazer um balanço do que ele chama de "teoria asiática da produção", sendo que Wittfogel (1966, p. 417-421) critica o 
etapismo stalinista e cita Franz Boas para reafirmar o prejuízo em se buscar leis gerais de evolução da humanidade.

Nesse sentido, mesmo que Stálin - e seu marxismo-leninismo - tenha negado o debate sobre a formação asiática, Marx, Engels e Lenin o aceitaram. 0 autor delineia as influências de Marx na interpretação do oriente e recupera a discussão feita por Lênin. Segundo Wittfogel (1966, p. 421-427), Lênin discute a sociedade asiática entre 1894 e 1914 reconhecendo sua natureza estagnada, pouco industrializada e apresentando uma restrita diferenciação de classes. Lênin, no entanto, teria abandonado a problemática em 1916, assim como Marx antes dele, ambos paralisados diante da descoberta da "real natureza" da sociedade oriental. Wittfogel ressalta que Lênin fala sobre o feudalismo russo, remetendo a uma estratégia para se apoderar da máquina estatal (Wittfogel, 1966, p. 444). Ao defender a posse da terra pelo poder central, Lênin se rende à restauração de um traço asiático, em contrapartida, Wittfogel minora o abandono do eurocentrismo promovido por Lênin ou, ainda, a possibilidade de revolução na periferia do capitalismo.

Para o autor, Marx demonstra "repugnância" ao discutir o caráter gerencial do despotismo, se recusando a admitir que a burocracia exerça a dominação social. Wittfogel induz o leitor a pensar que o marxismo resulta no totalitarismo comunista e que os cânones marxistas tentaram obliterar a teoria da sociedade asiática, uma vez que, convenientemente, tais figuras comporiam os próprios regimes despóticos. Independente disso, não é possível negar que Marx sempre usou a ideia de sociedade asiática com cautela e nunca negou propriamente essa concepção (McFarlane et al., 2005, p. 310).

Hindess e Hirst (1976, p. 217) fazendo uma avaliação sobre o balanço de Wittfogel, colocam que ele se pauta exacerbadamente na visão de oriente que Marx desenvolve, em 1853, no artigo sobre a dominação britânica da Índia e toda análise que foge desse escopo é classificada como um "recuo diante da verdade". Nosso autor, sem problematizar até as últimas consequências as elaborações de Marx, tem consciência que Engels foi o idealizador de uma explicação da sociedade asiática. Wittfogel (1966, p. 434-437) relembra que no Anti-Dühring, Engels retoma vários princípios do modo de produção asiático como o hidraulismo, a estagnação e a base sócioadministrativa e em $A$ origem da família, da propriedade privada e do Estado que exclui o debate sobre o oriente -, segundo Wittfogel, Engels se refere apenas ao 
ocidente e não às sociedades asiáticas. Nesse sentido, ele não identifica nenhuma ruptura no pensamento engelsiano.

Para reafirmar sua posição, nosso autor remonta ainda aos anarquistas:

Quando Marx escrevia a versão final do volume primeiro do Das Kapital estava em conflito aberto com os proudhonistas. E a partir do final dos anos [18]50, tanto ele como Engels se viram claramente molestados pelos bakunistas, segundo os quais 0 socialismo estatal levaria inevitavelmente consigo ao governo de uma minoria privilegiada sobre o resto da população, incluídos os trabalhadores (Wittfogel, 1966, p. 437).

Mobilizar o anarquismo para criticar o marxismo é um fato que, estrategicamente, posiciona Wittfogel dentre a esquerda não comunista, sem evidenciar suas novas credenciais no campo da direita. Seu argumento de que a opressão do Estado paralisa o desenvolvimento social é semelhante ao dos anarquistas como P. Kropotkin ou o próprio Bakhunin, contudo, sua tese não se sustenta do ponto de vista histórico, uma vez que se observa dentre as sociedades asiáticas significativas transformações históricas.

Ao avaliar o mundo que lhe é contemporâneo, nosso autor demonstra que mesmo no Peru pós-independência se reproduzem aspectos asiáticos como o reforço do exército e da burocracia. Na Turquia de Ataturk algo similar ocorreria, colocando este país na mesma situação que a Rússia pré-soviética. Ao retornar o tema da URSS, nosso autor admite que entre 1917 e 1922 existiu um governo popular com planejamento democrático, porém Lênin teria sido traído pela burocracia semiasiática, que encontrou na coletivização o caminho para a industrialização. Mao se alinharia, também, a essa orientação, coletivizando a terra e estabelecendo um sistema social de escravidão generalizada. Mesmo que ele reconheça a natureza campesina do Partido Comunista da China, a teoria promovida pela base ideológica do partido tende a minorar o poder do povo (Wittfogel, 1966, p. 485-495).

Na retórica da Guerra Fria, Wittfogel (1966, p. 495) destaca o poder que a China teria em influenciar a periferia do mundo capitalista. Sua postura é a de defender que, exceto o Japão, todos os países da Ásia estão suscetíveis ao marxismo-leninismo como proposta de modernização. Sua conclusão é que o processo de restauração asiática permite neutralizar a influência do ocidente e o comunismo possibilita a modernização por meio de um fortalecimento da dinâmica 
da "sociedade asiática", ou seja, a consolidação do despotismo agrário com desenvolvimento industrial (Wittfogel, 1966, p. 497).

Ademais, cabe destacar que Max Weber também inspirou a construção do Despotismo. Como indica Palerm (1978, p. 47), existe uma proximidade entre o modelo geral delineado por Wittfogel e o tipo ideal de Weber, autor que o influencia desde a juventude. Contudo, Hindess e Hirst (1976, p. 256) destacam que tratar a administração das sociedades pré-capitalistas como uma dinâmica gerencial moderna é um anacronismo. No caso de Weber e a análise sobre a burocracia, identifica-se que seu raciocínio remete principalmente ao Estado moderno que pressupõe economia monetária, em suma, a burocracia capitalista funciona de forma distinta das sociedades tradicionais. Assim:

Weber sustentava que os tipos de administração que poderiam melhor sobreviver no mundo pré-capitalista eram os que não pressupunham uma forma altamente centralizada ou 'gerencial'. Weber concebeu o sistema de dominação na China como carismático-tradicional; o funcionalismo chinês, longe de ser uma burocracia moderna, apresentava uma semelhança muito grande com o staff doméstico de um príncipe (administração central) e com o governo de uma pequena nobreza ajudada por representantes da administração central (administração local). Para Weber, as formas burocráticas eram exceção e não regra no mundo pré-capitalista; para Wittfogel a situação é inversa - o despotismo oriental 'gerencial' é o tipo social mais geral (Hindess e Hirst, 1976, p. 257-258).

Paralelamente, é importante ressaltar que, apesar de os membros da Escola de Frankfurt aproveitarem marginalmente as contribuições de Weber, assim como Wittfogel, Herbert Marcuse, desde 1934, utiliza o aporte weberiano para analisar a racionalização liberal do capitalismo. Diferentemente de Wittfogel, Marcuse demonstra "a racionalidade capitalista como formal, funcional, abstrata, 'indiferente' aos seres humanos, baseada nos cálculos numéricos e na redução da qualidade em quantidade" (Lowy, 2014, p. 121). Tal crítica da racionalidade capitalista pode ser coadunada facilmente com a leitura frankfurtiana da modernidade e do lluminismo, mesmo que, para a maior parte de seus membros, Weber tenha um papel menos importante.

Além dessa interpretação incoerente no tocante à China e à Índia, classificadas por Weber como estruturas sociais distintas em função de sua ética religiosa, existe um problema histórico-geográfico fundamental que não é evidenciado por Wittfogel, que diz respeito à estabilidade territorial. Se adotarmos 
uma visão retrospectiva a respeito da China, o que hoje nós convencionalmente admitimos como território chinês não pode ser aplicado ao passado, isso porque, as diversas dinastias da China tiveram dimensões territoriais diferentes. Em alguns casos, é possível identificar duas ou mais dinastias diferentes no mesmo território que corresponde à China atual - como no caso da dinastia Liao (907-1125) e Song (1127-1279). O próprio ocidente, no processo de colonização e descolonização, influenciou na promoção da instabilidade territorial, seja na China ou na Índia - neste último temos, por exemplo, a criação de Bangladesh e do Paquistão em meados do século XX. Em nenhum momento, a mutabilidade dos territórios é levada em consideração e encarada de uma maneira histórica, mesmo que o autor seja um geógrafo. Não existe uma explicação aprofundada da diferenciação histórica entre os períodos e as diferentes dinastias da China, elas são evocadas apenas para confirmar a estagnação e a hipótese do despotismo oriental.

\section{O eco do totalitarismo}

As credenciais de Wittfogel como marxista renegado permitiram que ele instrumentalizasse o marxismo para analisar o Oriente no auge do marcarthismo. Sua obra foi mal recebida pela direita e pela esquerda, e, em 1964, quando se inicia um processo de reabilitação da categoria do modo de produção asiático na URSS, sua obra ganha uma edição francesa.

O Despotismo é traduzido e publicado na França em 1964, contudo, Pierre Vidal-Naquet escreve um prefácio crítico que problematiza a obra. Quatro anos depois, é incluída na edição francesa uma "carta ao leitor" em que Wittfogel (1968, p. 2-6) se defende, ao dizer, basicamente, que sua obra trata de "estruturas sóciohistóricas pequenas, médias e grandes" e critica Vidal-Naquet por defender o socialismo real e seu caráter semiasiático.

Vidal-Naquet (1964, p. 533) é taxativo ao se referir ao iluminismo europeu: "[...] o déspota que, desde o fim da Idade Média se opõe ao soberano cristão é o 'rei do oriente'; tradição que com Jean Bodin ao fim do reinado de Luís XIV ganhou uma significação política cada vez mais precisa". Paralelamente, Vidal-Naquet (1964, p. 537-547) critica Wittfogel por imputar a Marx a culpa e gênese dos percalços do socialismo real, além de destacar que Lênin combateu e não reforçou a ideia de despotismo oriental, uma vez que os traços asiáticos seriam meras sobrevivências 
do passado. No tocante ao assunto, mesmo Trotsky hesitou em nomear a burocracia como uma classe social distinta dentro da URSS.

O balanço que até agora pudemos fazer sobre a trajetória de Wittfogel nos conduz a uma conclusão clara: nosso autor restaura várias ideias iluministas e não problematiza as fontes consultadas ou contexto em que os saberes sobre o oriente do século XIX - ou mesmo anteriores - foram construídos. Wittfogel reproduz uma visão eurocêntrica e essencialista do oriente, enquanto afirma que "o que caracteriza o universo concentracionário soviético é, em primeiro lugar, a obsessão pelo desenvolvimento" (Losurdo, 2010, p. 155). Nesse sentido, ele se encaixa em uma longa tradição intelectual do ocidente que reafirma a essência despótica do oriente e que mesmo nos dias de hoje tem um peso no debate público.

Alguns anos depois da publicação do Despotismo, Wittfogel lança um pequeno artigo demonstrando os resultados de sua teoria. Ele diz claramente que o sítio ecológico oferece a possibilidade ou a probabilidade, "mais do que a necessidade de certos tipos de ação" (Wittfogel, 1969, p. 361). Além disso, ele constrói uma genealogia de sua teoria, destacando as descobertas de cada intelectual na história das ideias: Adam Smith mostra uma política governamental agro hidráulica para os países do oriente; Herder e Hegel destacam o surgimento das civilizações orientais nas margens dos grandes rios (geo-hidráulica); Marx e Engels anunciam o surgimento de um Estado hidráulico; Max Weber demonstra o governo de uma casta burocrática que se impõe como Estado; e, finalmente, ele próprio descobre que a classe governante no interior da burocracia é responsável pela autocracia suprema (Wittfogel, 1969, p. 361). No entanto, é importante ressaltar que Wittfogel não oferece quase nenhum exemplo de sociedade oriental não hidráulica, salvo o Japão.

Cabe destacar, finalmente, que Wittfogel além de reabilitar a interpretação do despotismo oriental do iluminismo, acaba por se alinhar às figuras da esquerda não comunista que aderem à hipótese do totalitarismo. O uso dessa ideia para compreender o comunismo não é algo estranho ao seu círculo intelectual ampliado. Nesse sentido, Hanna Arendt em seu As origens do totalitarismo, de 1951, tem uma retórica semelhante a de Wittfogel. Pode-se destacar, no entanto, a possibilidade dessa afinidade de ideias surgir devido ao fato de ambos inspirarem a esquerda não comunista e, ao mesmo tempo, terem contato direto ou indireto com o serviço secreto estadunidense. Claramente, suas denúncias ao socialismo real estão em 
interlocução e certamente foram valorizadas pela política externa estadunidense (Saunders, 2008).

Losurdo (2003) faz uma recuperação de como a categoria de totalitarismo foi articulada no âmbito da esquerda - lembrando-se que esse debate tem reverberações em outros espectros políticos. De um lado, encontramos uma associação promovida por Simone Weil entre a centralização política ocorrida na Roma antiga, no governo Luís XIV e durante o hitlerismo. Em contrapartida, os próprios nazistas acusaram os soviéticos de conformarem um regime totalitário e ainda é possível encontrar na direita uma caracterização das democracias totalitárias relacionadas às revoluções de 1789, 1848 e 1917 (Losurdo, 2003, p. 5254).

Para Losurdo (2003, p. 55-56), a doutrina de Wittfogel não é adotada pela diplomacia estadunidense por ser agressiva, o que poderia ser contraproducente, principalmente, levando em conta o apoio a Chiang Kai-Schek, que iniciou sua carreira como um chefe político menor, após o esfacelamento do império chinês. Contudo, a lógica do anticomunismo de Wittfogel, a de Arendt e a da doutrina oficial da Guerra Fria é a mesma, ou seja, o totalitarismo deve ser caracterizado como uma consequência natural da ideologia comunista (Losurdo, 2003, p. 56-57).

Arendt delineia um raciocínio similar ao de Wittfogel: Lênin é visto como um político bem-intencionado, mas enganado pelos membros do partido, o que abre espaço para Stálin e seu governo totalitário. No novo sistema se conforma uma oposição entre o líder e a massa politicamente amorfa e desarticulada. Arendt, ainda, pinça alguns elementos afins do despotismo como a concepção de que o indivíduo não tem valor no oriente. Encontramos então uma visão ambivalente sobre o socialismo real, pois ora Arendt diz que o naufrágio da URSS ocorre pela passagem de poder dos sovietes para a burocracia, ora devido ao fatalismo inerente ao pensamento de Marx acrescido da ideia de autossacrifício moral, advinda da própria revolução (Losurdo, 2003, p. 60-61). Tanto o fatalismo marxiano, como o papel da burocracia estão presentes nas ideias de Wittfogel.

Como defende Linton (2011, p. 1-2), Wittfogel entrou no jogo da Guerra Fria em busca de uma audiência para suas ideias, ou ainda, para acumular capital cultural. Contudo, ele cai em descrédito a partir do momento em que foi incapaz de explicar a cisão entre a China comunista e a URSS ou mesmo os rumos da Guerra Fria. Apesar disso, Wittfogel argumenta que China e Rússia seriam despotismos levemente diferenciados: o primeiro é mais agrário e tradicional, enquanto o 
segundo é mais industrializado, tendo como resultado uma maior rigidez e intensidade do despotismo chinês em comparação ao russo (Linton, 2011,p. 92). Os acontecimentos da tentativa chinesa de polarizar a revolução cubana, a crise dos mísseis em Cuba, em 1962, a falta de apoio por parte da URSS no conflito por fronteiras entre China e Índia, a guerra do Vietnã e os acontecimentos no Camboja separam cada vez mais o destino das duas potências comunistas.

\section{Considerações Finais}

Karl A. Wittfogel, geógrafo relevante ligado ao marxismo e à Escola de Frankfurt, a partir da década de 1950 se rende ao anticomunismo. Como tentamos demonstrar sua obra O Despotismo Oriental, apesar de mobilizar muitas referências bibliográficas e figurar extensa erudição acaba reabilitando uma visão essencialista das sociedades asiáticas: elas são despotismos que encontram na doutrina marxista um caminho para se modernizarem. Argumentando a favor de uma interpretação parcial e equivocada do legado marxiano e dos marxistas, Wittfogel de forma indireta reabilita 0 argumento de Bakhunin em seu debate com Marx na Primeira Internacional, reafirmando que o poder corrompe seus possuidores. Eurocêntrico, nosso autor vê sociedades asiáticas em todos os cantos do mundo, salvo o Japão, parte da América do Norte e da Europa.

Acreditamos que sua obra controversa contribuiu para que o debate sobre 0 modo de produção asiático fosse abandonado. Figuras como Hobsbawn (1985) e Anderson (2004) acabam descartando tal conceito do pensamento marxiano, ao passo que Cardoso et alli (1990) demonstram que a hipótese hidráulica de Wittfogel não se sustenta, pois nem sempre o surgimento da irrigação acompanha a criação do Estado e, em vários casos, a administração hídrica foi conduzida pelo poder local. Para, Anderson (2004, p. 486) o Despotismo é um resquício do spencerianismo ou uma "[...] barafunda vulgar, desprovida de qualquer senso histórico, faz uma salada com Roma imperial, Rússia czarista, Arizona dos hopis, Peru dos incas, Turquia otomana e Mesopotâmia dos sumérios - para não falar de Bizâncio, Babilônia, Pérsia e Havaí".

Em uma resenha do Despotismo, o sinólogo J. Needham (1959, p. 58) associa claramente Wittfogel e a Guerra Fria, deixando claro que "[...] o livro, pode ser dito, constitui um dos maiores desserviços que já foram feitos ao objetivo de se fazer uma história da China". Outro aspecto ressaltado por Needham (1959, p. 62) é 
a tendência de se minorar as revoltas populares e de se valorizar o confucionismo em detrimento do taoismo e do budismo. Antes da Segunda Guerra Mundial, existia uma resistência à ideia de modo de produção asiático na China e no Japão. Masubuchi (1966, p. 316-319) acrescenta que, na década de 1930, Wittfogel foi traduzido para o japonês, mas quando o Despotismo adentra o ambiente intelectual nipônico sofre críticas. Ele não levou em consideração que tanto no Japão, quanto na China, uma parte da agricultura não precisava de irrigação.

Mesmo com o afastamento de Wittfogel dos demais frankfurtianos, é possível traçar paralelos entre suas análises. Da mesma forma que os frankfurtianos constroem uma visão pessimista sobre a razão instrumental científica, demonstrando como ela está na raiz da alienação e do fetiche da mercadoria no capitalismo, Wittfogel caracteriza uma racionalidade da sociedade oriental motivada pela manutenção do poder. Quando ele defende que a restauração asiática reflete uma sociedade arcaica que se industrializa, claramente a racionalidade do poder total se intensifica e ganha os contornos totalitários. Os frankfurtianos, ao contrário, admitem a possibilidade de uma racionalidade não instrumental, capaz de reconciliar o homem e a natureza em uma relação que não subtraia um dos dois componentes (Jay, 2008, p. 334). No fluxo da retórica da Guerra Fria, Wittfogel coloca como solução para o despotismo oriental o combate ao comunismo.

Apesar da repulsão e da atração que, contraditoriamente, sofre a obra de Wittfogel, como nos coloca Price (2008, p. 37), ele teve uma influência na antropologia norte-americana, impulsionando uma perspectiva que valoriza a ecologia por um viés materialista. Pouco se fala de seu determinismo geográfico, que, mesmo relativizado, associa o meio geográfico e o desenvolvimento de determinadas instituições sociais. Ironicamente, Wittfogel era um crítico contumaz da geopolítica nazista na década de 1930, mobilizando argumentos teóricos do marxismo e da geografia para demonstrar a ênfase exacerbada que K. Haushofer, por exemplo, dava à política. Mais de vinte anos depois Wittfogel, a nosso ver, incorre no mesmo erro, e ainda mais, cria um argumento teórico que justifica a posição geopolítica dos EUA na Guerra Fria.

Em 1971, quando Wittfogel reclama os direitos de uma publicação que reúne seus textos da juventude sobre o tema da estética, os editores alemães respondem que a obra foi publicada intencionalmente de forma ilegal, uma vez que Wittfogel já estaria morto há muito tempo para a teoria e prática marxista (Linton, 2011, p. 96). Apesar da controvérsia, não acreditamos que o modo de produção asiático e a 
discussão sobre a forma asiática marxiana deva ser descartada. Despidos de eurocentrismo e de essencialismo, tais conceitos, ainda, podem ajudar a compreender a especificidade geográfica das formações sociais. Seu correto uso serve para destruir pensamentos como o de Wittfogel que aspiram, ao fim e ao cabo, recriar um imaginário geográfico sobre o oriente a serviço do imperialismo.

\section{REFERÊNCIAS}

BERDOULAY, V. A abordagem contextual. In: Espaço e Cultura, n. 16, p. 47-56, 2003.

BOURDIEU, P. Science de la science et réflexivité. Paris: Éditions Raison d'agir, 2001.

BOURDIEU, P. Os usos sociais da ciência. São Paulo: Editora da Unesp, 2003.

CARDOSO, Ciro Flamarion (org.); BOUZON, Emanuel; TUNES, Cássio, M. de M. Modo de produção asiático - nova visita a um velho conceito. Rio de Janeiro: Campus, 1990.

CHANG, Ha-Joon. Chutando a escada. São Paulo: Editora Unesp, 2003.

CHENG, Ling-fang; FU, Daiwie. De l'orientalisation de la Chine à la occidentalisation de la Méditerranée. In Alliage, no 24-25, 1995.

GELBER, Harry G. O dragão e os demônios estrangeiros. Rio de Janeiro: Editora Record, 2012.

HINDESS, Barry e HIRST, Paul Q. Modo de produção pré-capitalista. Rio de Janeiro: Zahar Editores, 1976.

HOBSBAWN, E. Formações pré-capitalistas. São Paulo: Paz e Terra, 1985.

JAY, Martin. A imaginação dialética: a história da Escola de Frankfurt e do Instituto de pesquisas sociais. Rio de Janeiro: Contraponto, 2008.

LINTON, Matthew D. The transformation of Cain: Karl August Wittfogel's american acculturation and the Cold War, 1934-1963. Massachusetts: Dissertação de mestrado Brandeis University, 2011.

LOSURDO, Domenico. Stálin: história crítica de uma lenda negra. Rio de Janeiro: Editora Renavan, 2010.

LOSURDO, Domenico. Para uma crítica da categoria de totalitarismo. In Crítica Marxista, Campinas, ํㅡ 17, 2003.

LÖWY, Michael. A jaula de aço: Max Weber e o marxismo weberiano. São Paulo: Boitempo editorial, 2014.

MASUBUCHI, Tatsuo. Wittfogel's theory of oriental society (or hydraulic society) and the development of studies of chinese social and economic history in Japan. In The Developing Economies, vol. 4, № 3, p. 316-326, 1966.

MCFARLANE, Bruce; COOPER, Steve; JAKSIC, Mionir. The asiatic mode of production: a new phoenix? (part 1). In Journal of contemporary Asia, vol. 35, nㅜ 3, 2005.

NEEDHAM, Joseph. Book review: Oriental Despotism In Science and Society, no 23, 1959. 
PALERM, Angel. Sobre el modo asiático de producción y la teoria de la sociedad oriental: Marx y Wittfogel in ULMEN, G. L. (ed.). Society and history - essays in honor of Karl August Wittfogel. Paris/Nova York: Mouton Publishers, 1978.

PERRY, Peter J. Thirty years on: or, whatever happened to Wittfogel. In Policial geography Quarterly, vol. 7, no 1, 1988, p. 75-83.

PRICE, David H. "Materialism's free pass: Karl Wittfogel, McCarthism, and the "bureaucratization of guilt"' in DUSTIN, M. Wax (org.) Anthropology at the dawn of the Cold Wat: the influence of foundations, mccarthyism and the CIA. s.I. : Universidade de Michigan, 2008.

SAUNDERS, France S. Quem pagou a conta? A CIA na Guerra Fria da Cultura. São Paulo: Editora Record, 2008.

SOFRI, Gianni. O modo de produção asiático. Rio de Janeiro: Paz e Terra, 1977.

VIDAL-NAQUET, Pierre. Histoire et idéologie: Karl Wittfogel et le concept de 'mode de production asiatique'. In Annales. Économies, sociétés, civilizations, ano 19, no 3, 1964.

WITTFOGEL, Karl A. Results and problems of the study of oriental despotism in The journal of Asian studies, Association for Asian studies, vol. 28, ㄲo 2, 1969.

WITTFOGEL, Karl A. "Lettre au lecteur" in WITTFOGEL, Les despotisme oriental. Paris: Les Éditions de Minuit, 1968.

WITTFOGEL, Karl A. Despotismo oriental: estudio comparativo del poder totalitario. Madrid: Ediciones Guadarrama, 1966.

WITTFOGEL, Karl A. Le despotisme oriental. Paris: Les Éditions de Minuit, 1964.

WITTFOGEL, Karl A. The hydraulic civilizations in THOMAS JR. William L. (org.). Man's role in changing the face of the Earth. Chicago: The University of Chicago Press, 1956.

WITTFOGEL, Karl A. The oriental despotism. New Haven e Londres: Yale University Press, 1957.

ZHAO, Qiguang. Chinese mythology in the context of hydraulic society In Asian folklore studies, vol. 48, nํㅡ 2, 1989.

\section{NOTAS DE AUTOR}

\section{CONTRIBUIÇÃO DE AUTORIA}

Breno Viotto Pedrosa - Concepção. Coleta de dados, Análise de dados, Elaboração do manuscrito, revisão e aprovação da versão final do trabalho

\section{FINANCIAMENTO}

Não se aplica

CONSENTIMENTO DE USO DE IMAGEM

Não se aplica

APROVAÇÃO DE COMITÊ DE ÉTICA EM PESQUISA

Não se aplica

Declaro não haver conflito de interesse. 
adaptar, criar para qualquer fim, desde que atribua a autoria da obra.

\section{HISTÓRICO}

Recebido em: 20-05-2020

Aprovado em: 18-05-2021 